\title{
The Effectiveness of Inquiry-based Learning to Train the Students' Metacognitive Skills Based on Gender Differences
}

\section{Jan Hendriek Nunaki}

Universitas Papua, Indonesia, j.nunaki@unipa.ac.id

\section{Insar Damopolii}

Corresponding author, Universitas Papua, Indonesia, i.damopoli@unipa.ac.id

\section{Novri Youla Kandowangko}

Dr. Universitas Negeri Gorontalo, Indonesia, novrikandowangko@ung.ac.id

\section{Elya Nusantari}

Dr. Universitas Negeri Gorontalo, Indonesia, elyanusantari@ung.ac.id

In science learning like biology, metacognitive skill needs to be developed. Inquiry-based learning is a learning which may train students' metacognitive skill. This research aimed to: (1) determining the effectiveness of inquiry-based learning in training students' metacognitive skill, and (2) examining the influence of gender difference on the students' metacognitive skills after given the inquiry-based learning. This research used a 4-D research and development model, and one group pre-test and post-test design was applied for the effectiveness trial. The subject of this research was 70 students (35 male and 35 female) of class $\mathrm{X}$ Mathematics and Natural Science of Public Senior High School 01 Manokwari, Indonesia. This research employs lesson plan, student worksheet, students' book, expert-validated achievement test and focus group discussion as its instruments. The metacognitive skill data were obtained from metacognitive skill rubric. The data were analyzed using paired sample t-test and independent sample t-test. It was found that inquiry-based learning effectively trains students' metacognitive skill, and there is no significant difference between male students' metacognitive skill with that of female students. Further researches may examine the difference of male and female students' metacognitive skill based on grade, age or personality taught using inquiry-based learning.

Keywords: biology lesson, effectiveness, inquiry-based learning, gender, metacognitive skill

Citation: Nunaki, J. H., Damopolii, I., Kandowangko, N. Y., \& Nusantari, E. (2019). The Effectiveness of Inquiry-based Learning to Train the Students' Metacognitive Skills Based on Gender Differences. International Journal of Instruction, 12(2), 505-516. https://doi.org/10.29333/iji.2019.12232a 


\section{INTRODUCTION}

Human will always take educational processes throughout their life. Activities are performed in order to improve self-ability as a basis of human resource development. One of the educational processes is implemented in school, in which the educational activities focus more on learning and teaching process. Learning and teaching activities must be able to make students aware that education is a need.

In the implementation of learning, the development of metacognitive skills is greatly necessary. However, the development of metacognitive skill and talent depends on the availability of supporting quality education (Hogan, Dwyer, Harney, Noone, \& Conway, 2015). Schools need to prepare students to be lifetime science students, in which they must be taught to gain such skill and apply it to get across assignment boundaries, thus it will be helpful for them to make new assignments which are unknown to them, one of which is metacognitive skill (An \& Cao, 2014; Veenman \& Spaans, 2005). Further researches must investigate the underlying mechanism of metacognitive usage to monitor cognitive (de Boer, Donker, Kostons, \& van der Werf, 2018; Justice \& Dornan, 2001). Some experts are of the opinion that school curriculum must be designed in such a way to develop metacognitive skill as an effort of human change and evolution.

Senior high school students are reported to have higher level of cognitive monitoring than junior high school students or college students (Christopoulos, Rohwer Jr, \& Thomas, 1987). Future researches must develop metacognitive skill (Hogan et al., 2015; Sánchez-Alonso \& Vovides, 2007; Sperling, Richmond, Ramsay, \& Klapp, 2012). Metacognitive is correlated to students' academic success. High metacognitive skill is possessed by students who contribute to help themselves as individual and in group become more adaptive and flexible, who are able to solve problems in the community in this fast developing information era (Cano et al., 2018; Coutinho, 2007; de Boer et al., 2018; Demirel, Aşkın, \& Yağc1, 2015; Sperling, Howard, Staley, \& DuBois, 2004; Wang, Chen, Fang, \& Chou, 2014). These experts also recommend applying more activities which may improve metacognitive skill in learning environment.

Research conducted by some researches for the last seventeen years from 2001 to 2018 resulted in a suggestion to carry out, namely the necessity for learning activity which is able to train students' metacognitive skill for them to succeed in their academic field, to be able to adapt to a new environment, and to be able to face the rapidly increasing world's development. One of the possibly implemented learning strategies to train students' metacognitive skill is investigation-based learning namely inquiry-based learning.

In science education like biology subject, metacognitive skill is needed for students to well implement investigation. An effective science instruction is not only about learning improvement, but also helping students develop their long-term metacognitive skill and reconstruct conceptual and procedural knowledge (de Jager, Jansen, \& Reezigt, 2005). As students get older and to higher grade, they shift their monitoring activities from published text material to self-recorded notes (Zimmerman \& Martinez-Pons, 1990). In science education like biology subject, metacognition study takes place in growth period 
and is integrated more to researches which discuss the core purpose of science education (Zohar \& Barzilai, 2013).

Research results in science education currently show that the development of students' scientific thinking and inquiry skill always become the main and an important focus of metacognition researches (Zohar \& Barzilai, 2013). The investigation is effective for people with low achievement (Chen, Huang, \& Chou, 2016). However, this research does not find any significant effect on the given treatment, in which this study is limited in implementation and has small sample size in each sub-group, with 13 male and 22 female students for treatment class. This research suggests employing treatment with big sample size. Further researches may investigate the long-term effects of investigation and metacognitive on laboratory inquiry learning (Chen et al., 2016).

The review results of previous 72 researches consistently show that inquiry-based learning may, when it is supported with adequate matters, be more effective than other learning approaches (Lazonder \& Harmsen, 2016). Inquiry-based science learning makes students active, thus it is expected to support metacognitive skill development in the future (Seraphin, Philippoff, Kaupp, \& Vallin, 2012). Students become superior individuals and active learners in learning process when they have their metacognitive skill developed (Zull, 2012).

Inquiry-based learning is useful, has no negative effect on students' performance (Parappilly, Siddiqui, Zadnik, Shapter, \& Schmidt, 2013), and improves students' metacognitive skill (Schraw, Crippen, \& Hartley, 2006), that students who are successful in learning are those who master metacognitive.

Akyol \& Garrison, (2011) propose that students' metacognition becomes mature through explanation, inquiry and clarification, and, according to Makarova, Makarova, \& Varaksa, (2017) teachers show students how to procedurally think in problem solving, decision making, learning of which one they should start with, what to do first and further steps, checking and evaluating the appropriateness of their solution and examining what to do and whether it is or is not correctly performed. These activities are examples of metacognitive modeling.

In the last century, Inquiry-based learning has been used in junior and senior high schools' classroom (Lati, Supasorn, \& Promarak, 2012). Analysis on the survey data shows that $88 \%$ of students are comfortable in understanding science (Sheffield \& McIlvenny, 2014). Inquiry learning is effective for all types of students, from the least to the most intelligent, male and female students of all grades (Trna, Trnova, \& Sibor, 2012). On the other hand, metacognitive contributes to gender based difference in learning achievement (Yerdelen-Damar \& Peşman, 2013), and no significant gender based difference is found for Turkish students in online courses (Yukselturk \& Bulut, 2007). Researchers outside Indonesia, namely Bidjerano, (2005) and Liliana \& Lavinia, (2011) reported that female students' metacognitive is higher than that of male students'. This result is in line with research conducted by Indonesian researcher, Ramdiah, (2013) who reports the same results. However, other researchers outside Indonesia, namely Chen et al., (2016) and Indonesian researchers Suherman, Purwianingsih, \& Diana, 
(2018) report that the male students' metacognitive is higher than that of female students'.

The findings of several researchers between 2005 and 2018 show different results on students' metacognitive skill. There are inconsistencies in the results of conducted researches. Consider some suggestions from researchers to use inquiry-based learning to train students' metacognitive skills, inconsistent findings about students' metacognitive skills based on gender, and in Indonesia, inquiry-based learning is recommended in the implementation of curriculum 2013 based learning, Considering suggestions from several researchers dealing with the implementation of inquiry-based learning to train students metacognitive skill, inconsistency findings of gender-based metacognitive skill, and the use of inquiry-based learning in the implementation of curriculum 2013-based learning, this research then designs inquiry-based learning devices and tests them in a simple experiment in the classroom. The purposes of this research are: (1) to find out the effectiveness of inquiry-based learning to train students' metacognitive skill and (2) to find out the difference of male and female students' metacognitive skill before and after being taught using inquiry-based learning.

\section{METHOD}

\section{Research Design}

This is a multiyear research which follows research and development of the 4-D development model (Thiagarajan, Semmel, \& Semmel, 1974). This development model consists of 4 stages, namely Define, Design, Develop and Dissemination. In the first year, the teaching materials-oriented inquiry-based learning was developed for experts' validation and their effectiveness test in training students' metacognitive skill. The developed teaching materials are lesson plans, student books, student worksheets, and achievement tests. The developed teaching materials have been validated by three experts and Focus Group Discussion (FGD). The results of experts and FGD's validation showed that the teaching materials were valid and may be tested in class learning process. Result of validation was presented in International Conference (Damopolii, Nunaki, Nusantari, \& Kandowangko, 2018.) In this stage, the developed teaching materials will be tested for their effectiveness in the metacognitive skill of students of Public Senior High School 01 Manokwari, Indonesia. In addition, the difference in students' metacognitive skill was also investigated based on gender (male and female) in biology learning using inquiry-based learning. In the effectiveness trial, one group pre-test and post-test design experiment was employed as the teaching material.

\section{Sample}

The research's total subject was 70 students of class X Mathematics and Natural Science taught with teaching materials-oriented inquiry-based learning in biology subject. There were 35 male students and 35 female students. Samples were students between 15 and 16 years of age and were taken using purposive sampling, in which there were two types of classes in class X, namely Social and Science classes. The basic consideration of the sampling is that the research aims particularly at students sitting in X science class. 


\section{Data Collection}

Students' metacognitive skill is measured using Corebima rubric with scores $0-7$. (Corebima, 2009)

Score 7. Answer is correct. Student's answer is written in his / her own sentence. Answer is consistently and systematically ordered, logically written with correct grammar, and supported with analytically, evaluatively or creatively explained reason

Score 6. Answer is correct. Student's answer is written in his / her own sentence. Answer is consistently and systematically ordered, logically written with incorrect grammar, and supported with analytically, evaluatively or creatively explained reason

Score 5. Answer is correct. Student's answer is written in his / her own sentence. Answer is inconsistently and non-systematically ordered, logically written with incorrect grammar, and supported with analytically, evaluatively or creatively explained reason.

Score 4. Answer is correct. Student's answer is written not in his / her own sentence. Answer is consistently and systematically ordered, logically written with correct grammar, and supported with analytically, evaluatively or creatively explained reason.

Score 3. Answer is correct. Student's answer is written not in his / her own sentence. Answer is inconsistently and non-systematically ordered, logically written with incorrect grammar, and supported with analytically, evaluatively or creatively explained reason.

Score 2. Answer is less correct. Student's answer is written not in his / her own sentence. Answer is inconsistently and non-systematically ordered, logically written with incorrect grammar, and not supported with analytically, evaluatively or creatively explained reason.

Score 1. Answer is incorrect. Student's answer is written not in his / her own sentence. Answer is inconsistently and non-systematically ordered, logically written with incorrect grammar, and not supported with analytically, evaluatively or creatively explained reason.

Score 0. Student does not answer

The rubric was used on the learning outcome test. 9 learning outcome tests were validated by 3 experts, with result of validation of $95.83 \%$ (valid) and of reliability of 0.67 (reliable).

\section{Data Analysis}

The data were descriptively and inferentially analyzed. The descriptive analysis was in the form of mean metacognitive skill and standart deviation. The inferential analysis employs paired sample t-test to examine the difference in metacognitive skill before and after students have been taught using inquiry-based learning, and independent sample ttest was employed to examine the difference in male and female students' metacognitive skill before and after they have been taught used inquiry-based learning. 


\section{FINDINGS}

This research presents the effectiveness of inquiry-based learning in training students' metacognitive skill, and the difference of male and female students' metacognitive skill. The description of metacognitive skill data are presented in Table 1.

Table 1

Description of Pre-Test, Post-Test Metacognitive Skill Based on Gender Difference Data

\begin{tabular}{llll}
\hline Data & $\mathrm{N}$ & Mean & Std. Deviation \\
\hline Post-test & 70 & 71.56 & 12.87356 \\
\hline Pre-test & 70 & 43.00 & 9.63989 \\
\hline Male Pre-test & 35 & 42.06 & 10.74557 \\
\hline Female Pre-test & 35 & 43.94 & 8.44339 \\
\hline Male Post-test & 35 & 72.11 & 11.15867 \\
\hline Female Post-test & 35 & 71.00 & 14.53191 \\
\hline
\end{tabular}

Table 1 shows that students' mean metacognitive skill after they have been taught using inquiry-based learning increases for 28.56 . The pre-test difference in male and female students' metacognitive skill is 1.88 , and the post-test difference in male and female students' metacognitive skill is 1.11 . Significant difference in students' pre-test and post-test metacognitive skill is presented in Table 2, significant difference in male and students' pre-test metacognitive skill is presented in Table 3, and significant difference in males was obtained and students' post-test metacognitive skill is presented in Table 4.

Table 2

Results of Pair T-Test Analysis on Students' Metacognitive Skill Test

\begin{tabular}{llllll}
\hline & Mean & Std. Deviation & t & df & Sig \\
\hline Pair Post-test - Pre-test & 28.55714 & 11.13505 & 21.457 & 69 & 0.000 \\
\hline
\end{tabular}

Table 2 shows that $0.000<0.05$, which may be concluded that there is significant difference in students' metacognitive skill before and after they have been taught using inquiry-based learning. Based on these data, we may state that inquiry-based learning may train students' metacognitive skill.

Table 3

Pre-Test Difference in Male and Female Students' Metacognitive Skill

\begin{tabular}{llllll}
\hline & & $\mathrm{t}$ & $\mathrm{df}$ & Mean Difference & Sig. \\
\hline Pre-test & Equal variances assumed & 0.816 & 68 & 1.88571 & 0.417 \\
\hline
\end{tabular}

Table 3 shows metacognitive skill before treatment is given, that $0.417>0.05$, indicating that there is no significant difference in male and female students' metacognitive skill before they are taught using inquiry-based learning.

Table 4

Post-Test Difference in Male and Female Students' Metacognitive Skill

\begin{tabular}{llllll}
\hline & & $\mathrm{t}$ & $\mathrm{df}$ & Mean Difference & Sig. \\
\hline Post-test & Equal variances not assumed & -0.360 & 63.751 & -1.11429 & 0.720 \\
\hline
\end{tabular}

Table 4 shows that $0.720>0.05$, indicating that there is no significant difference in male and female students' metacognitive skill, after inquiry-based learning has been given. 


\section{DISCUSSION}

\section{The effectiveness of inquiry in metacognitive skill training}

Inquiry-based learning is recommended for use in $21^{\text {st }}$ century learning. The research results show that inquiry-based learning may train students' metacognitive skill. The author finds that inquiry-based learning effectively trains students' metacognitive skill to a level higher than previously. The initial mean metacognitive skill is 43.00 and increases to 71.56. This result complete the researches of Quintana, Zhang, \& Krajcik, (2005); Zhang, Hsu, Wang, \& Ho, (2015) that find that metacognitive contributes to students' inquiry capability improvement. It is also evident that inquiry-based learning may also develop students' metacognitive skill. If it is related to what is obtained, it can be revealed that there is two-way relationship in which students' metacognitive skill can help students' inquiry skill within inquiry-based learning, and reciprocally, inquirybased learning is effective in training students' metacognitive skill.

In this research, inquiry-based learning is implemented in school, started with any existing phenomena in students' surrounding environment. Students observe school environment to learn about new things. Inquiry-based learning makes students involved in many various learning activities. The concerned learning activities are in the form of reasoning, inquiring, hypothesizing, choosing information, problem solving, decision making, evaluating investigation results and making conclusion to answer any proposed hypothesis.

Investigation activities in inquiry make students be interested and motivated to learn, since they may directly observe biological object of observation and discuss in groups. According to Kramarski \& Dudai, (2009) feedback in group is a useful tool to improve metacognitive skill. With all activities in inquiry-based learning, students become active learner and have their metacognitive skill trained.

The results of this study also reveals the ineffectiveness of inquiry-based learning in a research using a small sample carried out by Chen et al., (2016) where the number of male students are only 13 and female students are 22 in each subgroup. When the number of samples used is bigger in number, in this study there are as many as 70 students, the results show that inquiry-based learning is effective to train students' metacognitive skill. The problems given by the teacher to be solved by students through investigation in inquiry-based learning make their metacognitive skill develop. According to Pennequin, Sorel, Nanty, \& Fontaine, (2010), improving students' problem-solving skill can be conducted through the development of students' metacognitive skill. The problems given by the teacher make students have to develop their metacognitive skills first, so that they will be followed by an increase in problem solving skill. When students are able to solve problems through investigation in inquirybased learning, the results of their investigation are good. Based on the final measurement results indicate that there is a significant increase in students' metacognitive skill using inquiry-based learning. According to Naimnule \& Corebima, (2018), metacognitive skill cannot develop on its own, but requires a learning strategy to develop it. The increase reveals that inquiry-based learning effectively trains students' 
metacognitive skill. In this study, the results shown have not achieved very good results, but are good at training students' metacognitive skill, so it needs to be further developed by evaluating and testing to obtain excellent results in the future.

\section{Gender based difference in metacognitive skill}

The research results show that there is no difference in male and female students' metacognitive skill. The author is of the opinion that students taught using inquiry-based learning have their metacognitive skill affected, however, not significantly different between male and female students. The results found contradict the results of previous researches conducted by Bidjerano, (2005); Carr \& Jessup, (1997); Liliana \& Lavinia, (2011); Ray, Garavalia, \& Gredler, (2003); Zimmerman \& Martinez-Pons, (1990) show that there is difference in male and female students' metacognitive skill, in which female students have higher metacognitive skill than male students. Researches conducted in Indonesia by Nurmaliah, (2009); Ramdiah, (2013) show that there is difference in male and female students' metacognitive skill, in which female students' metacognitive skill is higher than that of male students. Other researches conducted by Niemivirta, (1997); Chen, Huang, \& Chou, (2016); Suherman et al., (2018) show significant difference in male and female students' metacognitive skill, however, with male students' metacognitive skill higher than that of female students. The research results found have different conclusion with that found by the author, in which in the class that implements inquiry-based learning make students' metacognitive skill is equal. The equal students' metacognitive skill shows that there is no significant difference between male and female students' metacognitive skill. This finding is very different from the previous research findings conducted by researchers both in and outside Indonesia.

Ideally, classroom learning should make students' skill equal, not the other way around; make students' skill vary. Metacognitive skill is a skill considered special by first grade students (Veenman \& Spaans, 2005). This research was conducted in class X Mathematics and Natural Science, which is the first grade of senior high school. Students' metacognitive skill must be well prepared with equal level. If the metacognitive skill level is different, then students' performance and achievement will also differ. According to Sperling, Richmond, Ramsay, \& Klapp, (2012), Wang, Chen, Fang, \& Chou, (2014) metacognition has significant role in science achievement, and de Boer, Donker, Kostons, \& van der Werf, (2018) state that continuous use of metacognition will produce better learning results.

Inquiry-based learning is a collaborative learning. In this learning, male and female students are grouped into one same group, within which they collaborate in education process as an effort to solve a problem which must be solved. According to Bernard \& Bachu, (2015) collaborative learning improves metacognitive skill, and with this skill, students are able to identify and understand how to analyze and evaluate alternative solutions for the problem. For example, in this research, students are asked to investigate whether the school environment has ecosystem, biotic and abiotic components. Biotic and abiotic components are an authentic problem existing in the environment where they study. To conduct authentic investigation, students use their metacognitive skill as an effort to solve the problem of ecosystem components. Male 
and female students are directly, jointly involved in conducting investigation, and the investigation helps develop metacognitive skill. It may be viewed here that male and female students jointly conduct investigation and have their metacognitive skill equally developed. Afterwards, metacognitive skill measurement does not show significant difference in male and female students' metacognitive skill.

According to Zhang, (2018), male students use metacognitive skill more than female students do. Based on the results of this research, it is obvious that inquiry-based learning provides equal opportunities to all students. This research reveals that male and female students have the same opportunity to develop their respective metacognitive skills. This is what distinguishes the results of previous researches. In addition, the use of learning strategies in previous researches produces different metacognitive skills in male and female students. On the other hand, this research reinforces the opinion of Säälik, (2015) who states that the strategies used in learning relate to gender. Then, in order to avoid differences in metacognitive skills of male and female students, it is recommended that teachers use the same learning strategies in each class with the same material topics. Further research needs to be continued to reveal in detail the influence of student's age level, personality, students' initial knowledge about metacognitive skills.

\section{CONCLUSION AND SUGGESTION}

According to the author's findings, we may conclude that inquiry-based learning effectively trains students' metacognitive skill, especially Papuan Students, Indonesia. When male and female students learn in an inquiry-based learning class, no difference in metacognitive skill is found. Future researches need to study the difference of male and female student's metacognitive skill based on grade, age or personality taught using inquiry-based learning. Besides, the finding of this research could be a basis for the continuation of the research conducted by the author in the second year.

\section{ACKNOWLEDGEMENT}

The author would like to thank the Indonesian ministry of research, technology and higher education for its Research Fund Grant for joint research between colleges (Contract number 080/SP2H/LT/DRPM/ 2018). The author would also like to thank Fitri Mandasari, S.Pd and Yohanes A. Sibu, S.Pd for their help in arranging the research instruments.

\section{REFERENCES}

Akyol, Z., \& Garrison, D. R. (2011). Assessing metacognition in an online community of inquiry. The Internet and Higher Education, 14(3), 183-190.

An, Y.-J., \& Cao, L. (2014). Examining the effects of metacognitive scaffolding on students' design problem solving and metacognitive skills in an online environment. Journal of Online Learning and Teaching, 10(4), 552-568.

Bernard, M., \& Bachu, E. (2015). Enhancing the metacognitive skill of novice programmers through collaborative learning. In Metacognition: Fundaments, applications, and trends (pp. 277-298). Springer.

Bidjerano, T. (2005). Gender differences in self-regulated learning. Paper presented at the 
Annual Meeting of the Northeastern Educational Research Association, October 19-21, Kerhonkson, NY. Retrieved from http://files.eric.ed.gov/fulltext/ED490777.pdf

Cano, J., Hernandez, R., Pastor, R., Ros, S., Tobarra, L., \& Robles-Gomez, A. (2018). Developing metacognitive skills for training on information security. In Online Engineering \& Internet of Things (pp. 708-720). Springer.

Carr, M., \& Jessup, D. L. (1997). Gender differences in first-grade mathematics strategy use: Social and metacognitive influences. Journal of Educational Psychology, 89(2), 318.

Chen, S., Huang, C.-C., \& Chou, T.-L. (2016). The effect of metacognitive scaffolds on low achievers' laboratory learning. International Journal of Science and Mathematics Education, 14(2), 281-296.

Christopoulos, J. P., Rohwer Jr, W. D., \& Thomas, J. W. (1987). Grade level differences in students' study activities as a function of course characteristics. Contemporary Educational Psychology, 12(4), 303-323.

Corebima, A. D. (2009). Metacognitive skill measurement integrated in achievement test. Retrieved

from

http://ftp.recsam.edu.my/cosmed/cosmed09/AbstractsFullPapers2009/Abstract/Science

Parallel PDF/Full Paper/01.pdf

Coutinho, S. A. (2007). The relationship between goals, metacognition, and academic success. Educate , 7(1), 39-47.

Damopolii, I., Nunaki, J. H., Nusantari, E., \& Kandowangko, N. Y. (2018). Designing teaching material oriented towards inquiry-based learning in biology. In Advances in Intelligent Systems Research (AISR) (pp. 1-4). ATLANTIS PRESS.

de Boer, H., Donker, A. S., Kostons, D. D. N. M., \& van der Werf, G. P. C. (2018). Longterm effects of metacognitive strategy instruction on student academic performance: A metaanalysis. Educational Research Review, 24, 98-115. https://doi.org/https://doi.org/10.1016/j.edurev.2018.03.002

de Jager, B., Jansen, M., \& Reezigt, G. (2005). The development of metacognition in primary school learning environments. School Effectiveness and School Improvement, 16(2), 179-196.

Demirel, M., Aşkın, İ., \& Yağcı, E. (2015). An investigation of teacher candidates' metacognitive skills. Procedia-Social and Behavioral Sciences, 174, 1521-1528.

Hogan, M. J., Dwyer, C. P., Harney, O. M., Noone, C., \& Conway, R. J. (2015). Metacognitive skill development and applied systems science: A framework of metacognitive skills, self-regulatory functions and real-world applications. In Metacognition: Fundaments, applications, and trends (pp. 75-106). Springer.

Justice, E. M., \& Dornan, T. M. (2001). Metacognitive differences between traditional-age and nontraditional-age college students. Adult Education Quarterly, 51(3), 236-249.

Kramarski, B., \& Dudai, V. (2009). Group-metacognitive support for online inquiry in mathematics with differential self-questioning. Journal of Educational Computing Research, 40(4), 377-404.

Lati, W., Supasorn, S., \& Promarak, V. (2012). Enhancement of learning achievement and integrated science process skills using science inquiry learning activities of chemical reaction rates. Procedia-Social and Behavioral Sciences, 46, 4471-4475. 
Lazonder, A. W., \& Harmsen, R. (2016). Meta-analysis of inquiry-based learning: effects of guidance. Review of Educational Research, 86(3), 681-718.

Liliana, C., \& Lavinia, H. (2011). Gender differences in metacognitive skills. A study of the 8th grade pupils in Romania. Procedia-Social and Behavioral Sciences, 29, 396-401.

Makarova, E. A., Makarova, E. L., \& Varaksa, A. M. (2017). Education process visualization in metacognition development and sustainability. International Journal of Cognitive Research in Science, Engineering and Education (IJCRSEE), 5(2), 65-74.

Naimnule, L., \& Corebima, A. D. (2018). The correlation between metacognitive skills and critical thinking skills toward students' process skills in biology learning. Journal of Pedagogical Research, 2(2), 122-1345.

Niemivirta, M. (1997). Gender differences in motivational-cognitive patterns of selfregulated learning. Paper presented at the Annual Meeting of the American Educational Research Association, Chicago, IL.

Nurmaliah, C. (2009). Analisis keterampilan metakognisi siswa SMP Negeri di Kota Malang berdasarkan kemampuan awal, tingkat kelas, dan jenis kelamin. Jurnal Biologi Edukasi, 1(2), 18-21.

Parappilly, M., Siddiqui, S., Zadnik, M., Shapter, J., \& Schmidt, L. (2013). An inquiry-based approach to laboratory experiences: Investigating students' ways of active learning. International Journal of Innovation in Science and Mathematics Education, 21(5), 42-53.

Pennequin, V., Sorel, O., Nanty, I., \& Fontaine, R. (2010). Metacognition and low achievement in mathematics: The effect of training in the use of metacognitive skills to solve mathematical word problems. Thinking \& Reasoning, 16(3), 198-220.

Quintana, C., Zhang, M., \& Krajcik, J. (2005). A framework for supporting metacognitive aspects of online inquiry through software-based scaffolding. Educational Psychologist, 40(4), 235-244.

Ramdiah, S. (2013). Pengaruh strategi pembelajaran PQ4R terhadap keterampilan metakognitif dan hasil belajar biologi siswa putra dan putri kelas XI SMA di Kota Banjarmasin. In Proceeding Biology Education Conference: Biology, Science, Enviromental, and Learning (Vol. 10, pp. 96-102).

Ray, M. ., Garavalia, L. ., \& Gredler, M. . (2003). Gender differences in self-regulated learning, task value, and achievement in developmental college students. Paper presented at Annual Meeting of the American Educational Research Association. Chicago, IL. April 2125.

Säälik, Ü. (2015). Learning strategies explaining boys' and girls' reading performance in schools with different language. Procedia-Social and Behavioral Sciences, 180, 1649-1655.

Sánchez-Alonso, S., \& Vovides, Y. (2007). Integration of metacognitive skills in the design of learning objects. Computers in Human Behavior, 23(6), 2585-2595.

Schraw, G., Crippen, K. J., \& Hartley, K. (2006). Promoting self-regulation in science education: Metacognition as part of a broader perspective on learning. Research in Science Education, 36(1-2), 111-139.

Seraphin, K. D., Philippoff, J., Kaupp, L., \& Vallin, L. M. (2012). Metacognition as means to increase the effectiveness of inquiry-based science education. Science Education International, 23(4), 366-382. 
Sheffield, R. S., \& McIlvenny, L. (2014). Design and implementation of scientific inquiry using technology in a teacher education program. International Journal of Innovation in Science and Mathematics Education, 22(6), 46-60.

Sperling, R. A., Howard, B. C., Staley, R., \& DuBois, N. (2004). Metacognition and selfregulated learning constructs. Educational Research and Evaluation, 10(2), 117-139.

Sperling, R. A., Richmond, A. S., Ramsay, C. M., \& Klapp, M. (2012). The measurement and predictive ability of metacognition in middle school learners. The Journal of Educational Research, 105(1), 1-7.

Suherman, D. P., Purwianingsih, W., \& Diana, S. (2018). The analysis of self-efficacy and metacognitive and its relation with academic performance of high school students based on gender on genetics concept. Assimilation: Indonesian Journal of Biology Education, 1(1), 14-20.

Thiagarajan, S., Semmel, D. S., \& Semmel, M. I. (1974). Instructional development for training teachers of exceptional children. Indiana: Center for Innovation in Teaching the Handicapped.

Trna, J., Trnova, E., \& Sibor, J. (2012). Implementation of inquiry-based science education in science teacher training. Journal of Educational and Instruction Studies In the World, 2(4), 199-206.

Veenman, M. V. J., \& Spaans, M. A. (2005). Relation between intellectual and metacognitive skills: Age and task differences. Learning and Individual Differences, 15(2), 159-176.

Wang, J.-R., Chen, S.-F., Fang, I., \& Chou, C.-T. (2014). Comparison of Taiwanese and Canadian students' metacognitive awareness of science reading, text, and strategies. International Journal of Science Education, 36(4), 693-713.

Yerdelen-Damar, S., \& Peşman, H. (2013). Relations of gender and socioeconomic status to physics through metacognition and self-efficacy. The Journal of Educational Research, 106(4), 280-289.

Yukselturk, E., \& Bulut, S. (2007). Predictors for student success in an online course. Journal of Educational Technology \& Society, 10(2).

Zhang, L. (2018). Gender differences in metacognitive and cognitive strategy use and reading test performance. In Metacognitive and Cognitive Strategy Use in Reading Comprehension (pp. 131-145). Springer.

Zhang, W.-X., Hsu, Y.-S., Wang, C.-Y., \& Ho, Y.-T. (2015). Exploring the impacts of cognitive and metacognitive prompting on students' scientific inquiry practices within an elearning environment. International Journal of Science Education, 37(3), 529-553.

Zimmerman, B. J., \& Martinez-Pons, M. (1990). Student differences in self-regulated learning: Relating grade, sex, and giftedness to self-efficacy and strategy use. Journal of Educational Psychology, 82(1), 51.

Zohar, A., \& Barzilai, S. (2013). A review of research on metacognition in science education: Current and future directions. Studies in Science Education, 49(2), 121-169.

Zull, J. E. (2012). From brain to mind: Using neuroscience to guide change in education. Stylus Publishing, LLC. 